\title{
Corruption and Trade Protection: Evidence from Panel Data
}

\author{
Subhayu Bandyopadhyay* \\ $\&$ \\ Suryadipta Roy**
}

September 2006

\begin{abstract}
This paper provides new estimates of the effects of corruption and poor institutions on trade protection. It exploits data on several measures of trade protection including import duty, international trade taxes, and the trade-GDP ratio. The paper complements the literature on the relationship between corruption and trade reform. It deviates from the previous literature in several ways. First, unobserved heterogeneity among countries have been controlled with properly specified fixed effects exploiting the time dimension present in the dataset. Secondly, instead of using tariff and non-tariff barriers, more general measures of trade protection have been used. The issue of endogeneity of corruption with respect to trade policy has been addressed using proper instruments for corruption used in previous studies. Moreover, two separate institutional measures have been used in the same regression to estimate their comparative impacts on trade policy. In general, we find that corruption and lack of contract enforcement have strong impacts to increase trade protection and negative effects on trade openness.
\end{abstract}

*Corresponding author:

Associate Professor,

Department of Economics,

West Virginia University,

Morgantown, West Virginia 26505-6025, and, Research Fellow, IZA-Bonn.

Email: subhayu.bandyopadhyay@mail.wvu.edu.

** Visiting Assistant Professor,

Department of Economics,

Lawrence University,

Appleton, WI -54911.

Email: suryadipta.roy@lawrence.edu 


\section{Introduction}

The discussion on the effects of corruption on trade policy has its roots in the broad literature on the political economy of trade policy. Given that trade policies often deviate from first best solutions, this strand of the literature has focused on the endogeneity of trade policy. The primary explanation in this regard has been that policy makers do not maximize national welfare. They choose trade policies in response to demands from the special interest groups.

Given that trade policy is endogenous, it is natural for capitalist producers in import competing sectors to lobby governments for trade barriers, as has been argued among others by Olson (1965). Grossman and Helpman (1994) developed the "protection for sale" model where they took into account the strategic interactions between the government and the special interest groups. The outcome of this interaction is determined in an equilibrium where the government implements trade policies after taking into account the tradeoffs associated with receiving campaign contributions vis-àvis reduced consumers' welfare. Our paper complements this idea and shows that corrupt governments that are more susceptible to lobbying will extend higher levels of trade protection. The level of corruption in an economy can thus serve as a proxy for the amenability of the government to lobby pressures and trade policies are inherently more likely to be protectionist in corrupt countries. Our contention is that the level of trade protection is positively correlated with the level of corruption and that the latter is an important measure of institutional support for special interest groups. This should raise the ability of these groups to successfully lobby for protection. The paper estimates this effect using cross-country regressions over time. We have addressed the endogeneity of 
corruption by suitably instrumenting for it. The rest of the paper is organized as the following. Section-2 presents the literature review. Section-3 specifies the econometric model we use. Section-4 discusses the data. Section-5 presents the results. Section-6 concludes.

\section{Literature review}

One of the first papers to address the relationship between corruption and trade protection is Krueger (1974), who develops a formal model of rent seeking under quantitative restrictions on trade in a competitive framework. Bhagwati (1982) discussed different types of directly unproductive profit seeking activities in a welfare-theoretic framework. Bardhan (1997) presents a survey on the effects of corruption. Prior econometric research linking corruption and trade has mainly focused on the reverse causality from trade openness to corruption. Ades and Di Tella (1999) showed corruption to be negatively associated with competition from foreign firms. Wei (2000) showed "natural openness" to be negatively associated with higher corruption levels. Treisman (2000) also showed corruption to be associated with exposure to imports and exports, but could not find convincing instruments to control for reverse causality from corruption to trade openness. Gatti (2004) investigates whether the presence of barriers to international trade and capital flows is associated with higher corruption and suggests that the main impact of trade barriers on corruption comes through collusion between individuals and customs officials. Dutt (2006) examines whether trade protection increases bureaucratic corruption, while Lee and Azfar (2002) examines the effect of corruption on trade reforms. The latter, to our knowledge, is the only paper that looks at 
the effect of corruption on trade policy. They find higher levels of corruption to be associated with higher tariff and non-tariff barriers and conjectured that more corrupt countries delay their trade reform programs.

Based on Grossman and Helpman (1994) one may expect a positive correlation between corruption and trade protection. The idea is that a kleptocratic government shall attach a higher weight on producers' surplus (relative to consumer surplus) in its welfare maximization, given its susceptibility to lobbying pressures. This would enable import competing sectors to more effectively lobby for trade protection. Bandyopadhayay, Lahiri, and Roy (2006) present a theoretical model to explore the effect of asymmetry among member nations on the Customs Union (CU) common external tariff. One of their findings is that if nations remain on average equally susceptible to lobbying but the spread of their lobbying susceptibilities increases, then the CU tariff will rise.

Recent cross-country research suggests a negative association between investment, economic growth and high levels of corruption (Mauro 1995). Given that low-income countries generally tend to be more "closed" towards trade, ex ante we can expect corruption to go hand-in-hand with trade protection. We investigate this relationship using unbalanced panel data on corruption and trade protection for a group of 88 countries over the period 1982-'97. In general, our results show corruption to significantly increase trade protection (or to reduce the level of trade openness). This holds even after we use a set of control variables and account for comprehensive region and year fixed effects.

Our analysis departs from the existing literature in the following ways. We are the first to provide fairly robust estimates of the effects of corruption on trade protection 
(per se), rather than on trade volumes or changes in tariffs. Secondly, we undertake a panel specification using region and time fixed effects, instead of using an ordinary least squares (OLS) specification. Apart from the corruption variable, we have also used a variable describing the quality of institutions - "the risk of contract enforcement", as a control variable, along with corruption. This measure has been used by Anderson and Marcouiller (2002) within the context of a gravity model, where they find lack of contract enforcement to significantly reduce international trade. They argue that strong institutional support for trade among high income countries lowers transactions costs and consequently allows greater trade between rich countries. Our specification which uses both the corruption and the contract enforcement variable in the same regression allows us to make richer predictions in terms of the importance of the institutional indicators on trade policy.

\section{Econometric specification}

The existing work on the effect of corruption on trade protection (by Lee and Afzar, 2002) bases its results on pooled cross-section estimates and does not account for unobserved (or not included) heterogeneity between countries. In a panel specification, OLS estimates generally tend to be biased and inconsistent due to the correlation of the regressors with the unobserved fixed effects. In order to address this problem, we explicitly allow for region and time fixed effects in our regressions. The region fixed effects would capture the tendency for countries within a region to organize themselves into Free Trade Areas (FTA) or Customs Unions (CU). A fixed effects model with country-specific effects, on the other hand, will not be able to properly identify the 
estimates for the most important corruption variable, given little variability of the data within groups. For example, Dutt and Mitra (2005) note this problem. Moreover, such an approach also uses up large degrees of freedom and results in high multicollinearity between the country-specific effects and some of the right-hand side variables, thereby making the interpretation difficult. Use of region-specific effects also allows us to employ time constant variables as instruments for corruption and contract enforcement, something that would not have been possible with country-fixed effects. Time specific effects address the issue of regressor endogeneity due to correlation of the right-hand side variables with the error terms in other periods. They also capture any pattern that the countries exhibit as a group over the years, e.g., whether all countries tend to become more protectionist or less protectionist (especially since our data cover the period of signing the Uruguay Round negotiations and the launching of the WTO). Our main econometric specification is of the form:

$$
y_{i t}=\alpha+\lambda_{j}+\gamma_{t}+\theta \text { Corruption }_{i t}+X_{i t}^{\prime} \beta+e_{i t}
$$

where, $y_{i t}$ denotes the level of trade protection in country $i$ at time period $t, \alpha$ is the common intercept term, $\lambda_{j}-s$ are the region-specific effects, and $\gamma_{t}-s$ are the timespecific effects common to all countries. $X_{i t}$-s are the set of control variables in all the equations. Our first point of departure is the introduction of $\lambda_{j}$ and $\gamma_{t}$ in equation (1). The central variable of interest is the corruption variable, our proxy for the susceptibility of the government to lobbying pressures. We also perform robustness checks to test the validity of our hypotheses. In a dynamic context, the level of corruption may be endogenous with respect to trade policy. An improvement in institutions in a country can lead to a reduction in bureaucracy which in turn might lead a further lowering of 
corruption. Furthermore, as Rodrik (2000) has argued, trade reforms not only lead to a change in import prices but also result in institutional reforms. Hausman tests that were conducted suggest endogeneity of the corruption variable. Therefore, we performed a two-stage least squares estimation, where we instrument the corruption variable by a dummy variable indicating whether the country was a British colony. The British colonial heritage dummy has been found to be associated with significantly lower corruption in cross-country regressions and has been previously discussed as an instrument for corruption in the existing literature (La Porta et al, 1999; Treisman 2000, Acemoglu et al. 2001). We find this variable to be highly significant in all first-stage regressions for corruption in the presence of other control variables and hence used it as an instrument for corruption in the 2SLS regressions. This is our second departure from the previous literature.

\section{Data}

The key independent variable in this study is the International Country Risk Guide’s (ICRG) popular index for corruption in government. According to Knack and Keefer (1995), who used the variable to explain investment and economic growth, lower scores for this variable indicate greater likelihood for government officials to demand special payments and/or bribes connected with import and export licenses, exchange controls, tax assessment, policy protection and loans. This comes fairly close to capturing bureaucratic corruption as we have conceptualized it here. The other measure of institutional efficacy that we have used in this study is the repudiation of contracts by government that indicates the risk of a contract being annulled by the government due to 
indigenization pressures, change of government, or of its priorities. While the former variable is measured on a zero to six scale, the latter is measured on a zero to ten scale, where lower scores denote higher corruption levels or higher risk for repudiation of contract.

For ease of interpretation, we rescale both variables such that higher numbers indicate greater levels of corruption or lack of contract enforcement. The measure has both its well known advantages and disadvantages. On the positive side, the ICRG measures have more extensive coverage than other survey data. Moreover, since a single survey methodology has been used, it enables us to make cross-country comparisons. A negative is that they are based on subjective assessments and are therefore subject to measurement error. More importantly, it might be possible that the survey respondents notice a country to be attracting trade and investments at a rapid rate and hence automatically give it a lower corruption rating and vice versa. Given that we instrument for corruption or contract enforcement in our final specifications, we can significantly circumvent the issue of measurement error with the corruption variables.

We use three different measures of trade policy to test the robustness of our results as well as to test our hypothesis of the positive effect of corruption on trade protection - (a) total import duties collected as a percentage of total imports; (b) taxes on international trade collected as a percentage of total current revenue; and, (c) trade-GDP ratio. While import duties comprise of all levies collected on goods at the point of entry, taxes on international trade is a more general measure of protection and include import duties, export duties, profits of export or import monopolies, exchange profits, and exchange taxes. Trade-GDP ratio has been widely used in the literature as a measure of 
openness (for example, Sachs and Warner, 1995). The control variables included in the regressions are real per capita gross domestic product, government expenditure-GDP ratio, current account balance (as a percentage of GDP), and the size of the country denoted by the population size. Rodrik (1998) had posited a positive correlation between an economy's exposure to international trade and the size of its government expenditure. Countries also differ in their trade policies on the basis of their sizes as measured by real GDP. Underdeveloped countries with low levels of GDP might impose higher levels of trade protection than high income countries. Higher levels of current account deficits might also lead to imposition of higher levels of tariffs or import duties in order to generate tariff revenue. As Easterly and Rebelo (1993) have argued, poorer countries often resort to trade taxation as a means to replenish government revenue. Population size has been introduced in the regressions as a control for country size. Other than the corruption variables, the rest of the data have been obtained from the World Development

Indicators of the World Bank for various years. After eliminating countries with missing observations on all the variables, we arrive at an unbalanced panel of 88 countries over the time period 1982-'97, with any single country having at least three years of data.

\section{Results}

Table 1.a provides summary statistics for our variables for the 88-country sample and Table 1.b presents the correlation matrix for the corruption variables across the different measures of trade restrictions. OECD countries are generally found to impose very low levels of import duties on their imports as compared to the underdeveloped countries with the minimum value ranging from $0 \%$ for Belgium, Denmark, Spain, 
United Kingdom, Ireland, Netherlands, and Romania to a high of around 53\% for India. The standard deviation is greater for taxes on international trade with the maximum going up to almost $75 \%$ for Uganda. The greatest standard deviation across countries is displayed by variations in the level of trade-GDP ratio with a low of around $6 \%$ for Ghana to a high of over $400 \%$ for Singapore. In general, advanced countries tend to have low levels of protection as is apparent in the second table. Import duty, export duty, and international trade tax are all negatively correlated with the level of real GDP while the trade-GDP ratio is positively correlated with real GDP. Levels of trade protection, measured by the two indicators are positively correlated with the level of corruption and the lack of contract enforcement. On the other hand, the level of openness determined by the trade-GDP ratio is negatively correlated with the levels of corruption and contract enforcement. Both the institutional variables are negatively correlated with the level of real GDP, government expenditure, and current account deficit. The level of trade openness is positively correlated with real GDP, government expenditure, and the current account balance.

Table 2 presents the OLS estimates of the effect of corruption on trade protection (with and without control variables). While corruption appears with the correct sign in all the regressions, the variable loses significance when control variables are introduced in the regression on import duty. The variable is positive and significant for trade tax, while it is negative and significant in the case of trade-GDP ratio. The OLS regressions also show the low-income countries to have higher levels of trade protection in all the regressions. The middle-income countries are found to have higher levels of import 
duties and lower levels of trade-GDP ratio in comparison to the high-income countries (the excluded dummy variable in our regressions).

Given that OLS estimates are biased and inconsistent in panel regressions, we use the fixed effects specification given in equation (1) in order to control for individual heterogeneity in estimation. The results for the fixed region-and-time-effects are presented in Table 3. In case of the import duty, corruption is still not significant while it is significant in case of the trade tax and the trade-GDP ratio. For the international trade tax, a one standard-deviation increase in corruption is associated with a 0.096 standard deviation increase in the tax. Trade tax is also negatively correlated with real GDP, government expenditure, current account balance, and population. In the regression on trade openness, a one standard-deviation increase in the level of corruption is associated with a 0.23 standard deviation reduction in the trade-GDP ratio. However, real GDP, government expenditure, and the level of current account balance are not significant with respect to the level of openness. The population variable is significant and negative, showing that an increase in the population size reduces the level of openness.

As discussed above, there might be an issue of endogeneity between the level of corruption and trade protection in a cross-country context. Keeping this in mind, Hausman tests were conducted that rejected the null hypotheses of exogeneity of the corruption variable. We took care of this endogeneity by instrumenting for corruption in a two-stage least squares regression where a dummy variable indicating the past colonial origins of the country was used as the instrument. This variable was also found to be negative and highly significant in a first-stage regression for corruption in the presence of other control variables. The colony dummy was partly constructed from Demirguc-Kunt 
and Levine (2001) for the majority of the countries in our dataset. Data on colonial origins for the rest of the countries were obtained from the Wikipedia website (http://en.wikipedia.org/wiki/British_Empire). The results for the two-stage least squares regressions are reported in Table 4. Corruption is found to be highly significant in all the regressions for import duty, international trade tax, and the trade-GDP ratio. Moreover, the effects of corruption on trade protection are also substantially larger after correcting for endogeneity. A one standard deviation increase in corruption is associated with 1.23 and 0.5 standard deviation increases in import duty and international trade tax, respectively, while the trade-GDP ratio is reduced by almost 4\%. Both real GDP and government expenditure, however, change signs in case of the instrumental variable regression. Both the variables are positively correlated with import duty, negatively correlated with the level of openness measured by the trade-GDP ratio, and are not significant in case of taxes on international trade. The change in the signs can be attributed to the correlation of the instrument variable used in the regression with the other explanatory variables used in the regression, namely real GDP, government expenditure, current account balance, and population.

As Anderson and Marcoullier (2002) have argued, lack of contract enforcement adds to the transactions cost between North-South trade and significantly reduces the trade volume. In order to estimate the effect of contract enforcement on trade policy and trade protection, we re-estimated equation (1) using both the measures of corruption and contract enforcement, along with other control variables. Given the endogeneity issue affecting both these indicators, it might be advisable to instrument both the variables. In order to do this, we used an index for linguistic fractionalization developed by Alesina et 
al. (2003) for about 190 countries along with the colony dummy variable. Indices based on ethnolinguistic fractionalization ${ }^{1}$ have been widely used in the corruption and growth literature in order to explain differing outcomes in terms of output and investment in cross-sectional regressions (Mauro 1995, Easterly and Levine 1997, La Porta et al. 1999). Linguistic fractionalization itself has been found to be associated with negative outcomes on government policies and quality of institutions. The linguistic fractionalization index came out to be highly significant and positively correlated with the corruption variable and negatively correlated with the contract enforcement variable in our first stage regressions (while the colony dummy variable was negatively significant in both the regressions) in the presence of other control variables.

Results of our fixed effects IV regressions are reported in table 5. In the presence of corruption, contract enforcement is highly significant and positive both in the case of import duty and the international trade tax, while it is negatively correlated with the trade-GDP ratio. This can be interpreted as follows: for a given level of corruption, an increase in the risk of government's repudiation of contracts leads to increased lobbying by the producers so as to minimize the chances of the government backing out on its promises. The increased lobbying leads to higher protection in the form of import duties or trade taxes or adds on to the transactions cost of trade so as to reduce the trade-GDP ratio. One standard-deviation increase in the risk of contract enforcement is found to lead to a 1.96 standard deviation increase in the import duty and a 0.91 standard deviation

\footnotetext{
${ }^{1}$ Index of ethnolinguistic fractionalization measures the probability that two randomly selected people from a given country will not belong to the same ethnolinguistic group. The linguistic fractionalization index used here measures the probability that any two randomly selected individuals will not speak the same language. The former measure, first introduced in the corruption literature by Mauro (1995) is indicative of the effect that ethnic heterogeneity in a country has on the State's redistributive policies.
} 
increase in the level of the international trade tax. The effect of the risk of contract enforcement on trade openness is especially severe, with a one standard deviation increase in the risk being associated more than 5 standard deviation reductions in the trade-GDP ratio, a result similar to Anderson and Marcouiller (2002). The corruption variable, however, turns out not to be significant in the presence of the contract enforcement variable. Given that the language (instrument) variable is more strongly correlated than the colony variable with the level of corruption, the effect of this variable dominates in our IV regressions, and renders the corruption variable insignificant (with a wrong sign) when contract enforcement is added on to the regressions.

\section{Conclusions}

The study thus provides fresh evidence on the effect of institutions on trade protection in particular, and trade policy in general. This has been done using crosscountry data for a diverse group of countries over a period of time. In general, we conclude that poor quality of institutions, measured by our corruption variable and lack of contract enforcement, significantly increases import duties and taxes on international trade, and reduces the level of openness, the latter measured by the trade-GDP ratio. However, our contention is that the signs of the coefficients reported in the regressions are more important than the (absolute) value of the coefficients. The findings provide indirect support for the Grossman-Helpman framework, because it supports the hypothesis of increased amenability of the government to lobbying pressures leading to higher levels of trade protection. 


\section{References}

Acemoglu, Daron, Simon Johnson, and James. A. Robinson, 2001, “The Colonial Origins of Comparative Development: An Empirical Investigation,” American Economic Review, 91 (5), 1369-1401.

Ades, Alberto, and Rafael Di Tella, 1999, "Rents, Competition and Corruption,” American Economic Review, 89(4), 982-994.

Alesina, Alberto, Arnaud Devleeschauwer, William Easterly, Sergio Kurlat, and Romain Wacziarg, 2003, “Fractionalization,” Journal of Economic Growth, 8(2), 155-94.

Anderson, James E. and Douglas Marcouiller, 2002, “Insecurity and the Pattern of Trade: An Empirical Investigation.” Review of Economics and Statistics, 84(2), 342-52.

Bandyopadhyay, Subhayu, Sajal Lahiri, Suryadipta Roy, 2006, “CU or FTA? The Role of Political Asymmetries”, Working paper series, West Virginia University.

Bardhan, Pranab, 1997, “Corruption and Development: A Review of Issues,” Journal of Economic Literature, 35(3), 1320-46.

Bhagwati, Jagdish N., 1982, "Directly Unproductive, Profit-seeking (DUP) Activities,” Journal of Political Economy, 90(5), 988-1002.

Demirguc-Kunt, Asli, and Ross Levine, 2001, eds. "Financial Structure and Economic Growth: A Cross-Country Comparison of Banks, Markets, and Development," Cambridge and London: MIT Press.

Dutt, Pushan, 2005, “Does Protection Beget Corruption?” INSEAD Working Paper Series. 
Dutt, Pushan, and Devashish Mitra, 2005, "Political Ideology and Endogenous Trade Policy: An Empirical Investigation.” The Review of Economics and Statistics, 87(1), 59-72.

Easterly, William, and Sergio Rebelo, 1993, Marginal Income Tax Rates and Economic Growth in Developing Countries,” European Economic Review, 37(2-3), 409-17.

Easterly, William, and Ross Levine, 1997, “Africa's Growth Tragedy: Policies and Ethnic Divisions,” Quarterly Journal of Economics, 112(4), 1203-50.

Gatti, Roberta, 2004, "Explaining Corruption: Are Open Countries Less Corrupt?" Journal of International Development, 16(6), 851-61.

Grossman, Gene M. and Elhanan Helpman, 1994, "Protection for Sale," American Economic Review, 84(4), 833-50.

Knack, Stephen, and Philip Keefer, 1995, "Institutions and Economic Performance: Cross-Country Tests Using Alternative Institutional Measures,” Economics and Politics, 7(3), 207-27.

Krueger, Anne O., 1974, "The Political Economy of the Rent-Seeking Society," American Economic Review, 64(3), 291-303.

La Porta, R., F. Lopez-de-Silanes, Andrei Shleifer and Robert Vishny, 1999, “The Quality of Government,” The Journal of Law, Economics, \& Organization, 15(1), 222-279.

Lee, Young, and Omar Azfar, 2002, “Does Corruption Delay Trade Reform?” Working Paper, IRIS Center, University of Maryland.

Mauro, Paolo, 1995, “Corruption and growth.” Quarterly Journal of Economics, 110(3), $681-712$. 
Olson, Mancur, 1965, “The Logic of Collective Action,” Harvard University Press.

Rodrik, Dani, 2000, “Trade Policy Reform as Institutional Reform.” Mimeo.

Rodrik, Dani, 1998, "Why Do More Open Economies Have Bigger Governments?” Journal of Political Economy, 106(5), 997-1032.

Sachs, Jeffrey D. and Andrew M. Warner, 1995, "Economic Reform and the Process of Global Integration,” Brookings Papers on Economic Activity, 0(1), 1-95.

Treisman, Daniel, 2000, “The Causes of Corruption: A Cross-National Study,” Journal of Public Economics, 76(3), 399-457.

Wei, Shang-Jin, 2000, "Natural Openness and Good Government," National Bureau of Economic Research, Inc, NBER Working Papers, \# 7765. 
Table 1.a: Summary Statistics

\begin{tabular}{|c|c|c|c|c|c|}
\hline Variable & Obs. & Mean & Std. Dev. & Min & Max \\
\hline Corruption & 1056 & 2.383 & 1.521 & 0 & 6 \\
\hline $\begin{array}{c}\text { Contract } \\
\text { enforcement }\end{array}$ & 1056 & 3.077 & 2.255 & 0 & 9 \\
\hline $\begin{array}{c}\text { Real gross } \\
\text { domestic } \\
\text { product }\end{array}$ & 1056 & 7.989 & 10.305 & 0.085 & 47.821 \\
\hline $\begin{array}{l}\text { Government } \\
\text { expenditure }\end{array}$ & 1056 & 15.564 & 5.967 & 2.975 & 43.479 \\
\hline $\begin{array}{l}\text { Current } \\
\text { account } \\
\text { balance }\end{array}$ & 1056 & $\begin{array}{l}-2.718 \\
\end{array}$ & 6.709 & -44.839 & 29.952 \\
\hline Population & 1056 & 50580.97 & 146786.5 & 239 & 1230075 \\
\hline Import duty & 1056 & 10.391 & 9.254 & 0 & 53.082 \\
\hline $\begin{array}{l}\text { International } \\
\text { trade tax }\end{array}$ & 1056 & 13.476 & 12.867 & 0 & 75.317 \\
\hline $\begin{array}{c}\text { Trade-GDP } \\
\text { ratio }\end{array}$ & 1056 & 65.538 & 47.201 & 6.32 & 406.75 \\
\hline
\end{tabular}


Table 1.b: Correlation matrix for trade protection, corruption, \& contract enforcement

\begin{tabular}{|c|c|c|c|c|c|}
\hline & Corruption & $\begin{array}{c}\text { Contract } \\
\text { enforcement }\end{array}$ & Import duty & $\begin{array}{c}\text { International } \\
\text { trade tax }\end{array}$ & $\begin{array}{c}\text { Trade-GDP } \\
\text { ratio }\end{array}$ \\
\hline Corruption & 1 & 0.66 & 0.46 & 0.53 & -0.21 \\
\hline Contract & 0.66 & 1 & 0.55 & 0.63 & -0.21 \\
enforcement & 0.46 & 0.55 & 1 & 0.66 & -0.22 \\
\hline Import duty & 0.53 & 0.63 & 0.66 & 1 & -0.09 \\
\hline International & & & & & \\
trade tax & -0.21 & -0.21 & -0.22 & -0.09 & \\
\hline $\begin{array}{c}\text { Trade-GDP } \\
\text { ratio }\end{array}$ & & & & & \\
\hline
\end{tabular}


Table 2: OLS regression

\begin{tabular}{|c|c|c|c|c|c|c|}
\hline & $\begin{array}{l}\text { Import } \\
\text { duty }\end{array}$ & Trade tax & $\begin{array}{c}\text { Trade-GDP } \\
\text { ratio }\end{array}$ & $\begin{array}{l}\text { Import } \\
\text { duty }\end{array}$ & Trade tax & $\begin{array}{c}\text { Trade-GDP } \\
\text { ratio }\end{array}$ \\
\hline Corruption & $\begin{array}{l}.117^{* * *} \\
(0.224)\end{array}$ & $\begin{array}{c}.205 * * * \\
(.348)\end{array}$ & $\begin{array}{c}-.155 * * * \\
(1.599)\end{array}$ & $\begin{array}{l}.049 \\
(.23)\end{array}$ & $\begin{array}{c}.116 * * * \\
(.329)\end{array}$ & $\begin{array}{l}-.117^{* *} \\
(1.504)\end{array}$ \\
\hline Real GDP & $\begin{array}{c}-.534 * * * \\
(.031)\end{array}$ & $\begin{array}{c}-.392 * * * \\
(.041)\end{array}$ & $\begin{array}{c}.002 \\
(.215)\end{array}$ & $\begin{array}{c}-.449 * * * \\
(.041)\end{array}$ & $\begin{array}{c}-.344^{* * *} \\
(.049)\end{array}$ & $\begin{array}{c}-.163 * * \\
(.327)\end{array}$ \\
\hline $\begin{array}{l}\text { Government } \\
\text { expenditure }\end{array}$ & $\begin{array}{c}.064 * * \\
(.04)\end{array}$ & $\begin{array}{c}-.072 * * \\
(.067)\end{array}$ & $\begin{array}{r}.037 \\
(.346)\end{array}$ & $\begin{array}{c}.071 * * * \\
(.041)\end{array}$ & $\begin{array}{c}-.075 * * \\
(.072)\end{array}$ & $\begin{array}{c}.012 \\
(.395)\end{array}$ \\
\hline $\begin{array}{l}\text { Current } \\
\text { account } \\
\text { balance }\end{array}$ & $\begin{array}{l}.051 * * \\
(.032)\end{array}$ & $\begin{array}{c}-.112 * * * \\
(.049)\end{array}$ & $\begin{array}{l}.114^{* *} \\
(.323)\end{array}$ & $\begin{array}{c}.105^{* * *} \\
(.145)\end{array}$ & $\begin{array}{l}-.032 \\
(.051)\end{array}$ & $\begin{array}{l}.099 * * \\
(.351)\end{array}$ \\
\hline $\begin{array}{l}\text { Population } \\
\left({ }^{\prime} 000,000\right)\end{array}$ & $\begin{array}{c}0.127 * * \\
(.0004)\end{array}$ & $\begin{array}{c}-.023 \\
(.0002)\end{array}$ & $\begin{array}{c}-.172 * * * \\
(.0009)\end{array}$ & $\begin{array}{c}.091 * \\
(.0003)\end{array}$ & $\begin{array}{c}-.072 * * * \\
(.0002)\end{array}$ & $\begin{array}{c}-.155^{* * *} \\
(.0008)\end{array}$ \\
\hline Low income & & & & $\begin{array}{l}.288 * * * \\
(1.075)\end{array}$ & $\begin{array}{l}.325 * * * \\
(1.641)\end{array}$ & $\begin{array}{c}-.262 * * * \\
(6.495)\end{array}$ \\
\hline Mid income & & & & $\begin{array}{l}.089 * \\
(.874)\end{array}$ & $\begin{array}{c}.025 \\
(1.283)\end{array}$ & $\begin{array}{c}-.223 * * * \\
(7.296)\end{array}$ \\
\hline $\begin{array}{c}\text { No. of } \\
\text { observations }\end{array}$ & 1056 & 1056 & 1056 & 1056 & 1056 & 1056 \\
\hline R-square & 0.36 & 0.39 & 0.08 & .40 & .47 & .10 \\
\hline
\end{tabular}

$*_{\text {- }}$ significant at $10 \%$ level; $* *_{\text {- }}$ significant at $5 \%$ level; $* * *_{\text {- }}$ significant at $1 \%$ level; standardized beta coefficients in each cell; robust standard errors in parentheses. 
Table 3: Fixed effects model with time-specific \& comprehensive region-specific effects

\begin{tabular}{|c|c|c|c|}
\hline & Import duty & Trade tax & Trade-GDP ratio \\
\hline Corruption & .009 & $.096^{* * *}$ & $-.231^{* * *}$ \\
& $(.235)$ & $(.34)$ & $(1.691)$ \\
\hline Real GDP & $-.213^{* * *}$ & $-.145^{* * *}$ & -.017 \\
& $(.028)$ & $(.044)$ & $.381)$ \\
\hline Government expenditure & $-.052^{*}$ & $-.234^{* * *}$ & .045 \\
& $(.044)$ & $(.07)$ & $.277)$ \\
\hline Current account balance & .016 & $-.167^{* * *}$ & .054 \\
& $(.022)$ & $(.043)$ & $-.227^{* * *}$ \\
\hline Population & $.102^{* * *}$ & $-.109^{* * *}$ & $(.00001)$ \\
\hline ('000,000) & $(.0004)$ & $(.0002)$ & 16 \\
\hline No. of years & 16 & 16 & 66 \\
\hline Average \# of countries & 66 & 66 & 0.26 \\
\hline each year & & 0.58 & $1 \%$ \\
\hline Overall R-square & 0.48 & & \\
\hline$*$
\end{tabular}

*- significant at $10 \%$ level; ${ }^{* *}$ - significant at $5 \%$ level; ***- significant at $1 \%$ level; standardized beta coefficients in each cell; robust standard errors in parentheses. 
Table 4: Fixed effects IV model with time-specific and comprehensive region-specific effects

\begin{tabular}{|c|c|c|c|}
\hline & Import duty & Trade tax & Trade-GDP ratio \\
\hline Corruption & $1.232^{* * *}$ & $.514^{* *}$ & $-3.588^{* * *}$ \\
& $(2.065)$ & $(2.049)$ & $(27.499)$ \\
\hline Real GDP & $.369^{* *}$ & .054 & $-1.618^{* * *}$ \\
& $(.148)$ & $(.146)$ & $(1.929)$ \\
\hline Government expenditure & $.274^{* *}$ & -.123 & $-.842^{* * *}$ \\
\hline Current account balance & $(.146)$ & $(.15)$ & .095 \\
& .001 & -.172 & $(.659)$ \\
\hline Population & $(.059)$ & $(.046)$ & $-.382^{* * *}$ \\
\hline ('000,000) & $.158^{* *}$ & $-.09^{* * *}$ & $(.00003)$ \\
\hline No. of years & $(.0004)$ & $(.0002)$ & 16 \\
\hline Average \# of countries & 16 & 16 & 66 \\
\hline each year & 66 & 66 & 0.06 \\
\hline Overall R-square & & 0.52 & \\
\hline$*$ & 0.22 & & \\
\hline
\end{tabular}

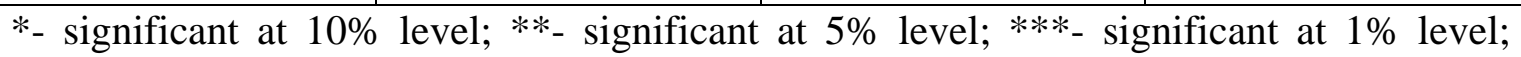
standardized beta coefficients in each cell; robust standard errors in parentheses. 
Table 5: Fixed effects model with time-specific and comprehensive region-specific effects (with contract enforcement)

\begin{tabular}{|c|c|c|c|}
\hline & Import duty & Trade tax & Trade-GDP ratio \\
\hline Corruption & $\begin{array}{l}-.489 \\
(2.139)\end{array}$ & $\begin{array}{l}-.284^{*} \\
(1.408)\end{array}$ & $\begin{array}{c}.811 \\
(28.117)\end{array}$ \\
\hline Contract enforcement & $\begin{array}{l}1.959 * * * \\
(2.493)\end{array}$ & $\begin{array}{l}.909 * * \\
(2.105)\end{array}$ & $\begin{array}{l}-5.007^{* * *} \\
(33.968)\end{array}$ \\
\hline Real GDP & $\begin{array}{l}.183 \\
(.122)\end{array}$ & $\begin{array}{l}-.032 \\
(.108)\end{array}$ & $\begin{array}{c}-1.141^{* * *} \\
(1.56)\end{array}$ \\
\hline Government expenditure & $\begin{array}{l}.019 \\
(.116)\end{array}$ & $\begin{array}{l}-.24 * * * \\
(.093)\end{array}$ & $\begin{array}{l}-.199 \\
(1.606)\end{array}$ \\
\hline Current account balance & $\begin{array}{l}.159^{* *} \\
(.087)\end{array}$ & $\begin{array}{l}-.098^{* *} \\
(.072)\end{array}$ & $\begin{array}{l}-.31^{*} \\
(1.127)\end{array}$ \\
\hline $\begin{array}{l}\text { Population } \\
\text { ('000,000) }\end{array}$ & $\begin{array}{l}.261^{* * *} \\
(.0004)\end{array}$ & $\begin{array}{l}-.043 \\
(.0003)\end{array}$ & $\begin{array}{l}-.644^{* * *} \\
(.00005)\end{array}$ \\
\hline No. of years & 16 & 16 & 16 \\
\hline $\begin{array}{c}\text { Average \# of countries } \\
\text { each year }\end{array}$ & 66 & 66 & 66 \\
\hline Overall R-square & 0.25 & $\begin{array}{l}0.53 \\
\end{array}$ & 0.03 \\
\hline
\end{tabular}

*- significant at $10 \%$ level; **- significant at $5 \%$ level; ***- significant at $1 \%$ level; standardized beta coefficients in each cell; robust standard errors in parentheses. 